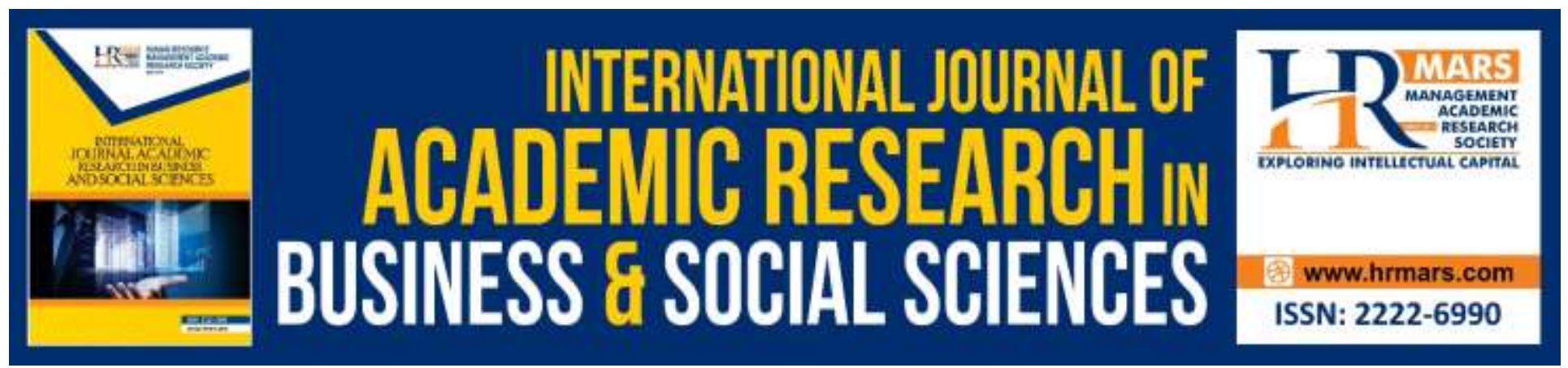

\title{
Vernacular Architecture in Old Malay Building through Malay Historiography
}

Siti Rabiatul Adawiah Jaffar, Arba'ie Sujud, Salmah Jan Noor Muhammad

To Link this Article: http://dx.doi.org/10.6007/IJARBSS/v10-i2/6927

DOI:10.6007/IJARBSS/v10-i2/6927

Received: 30 December 2019, Revised: 10 January 2020, Accepted: 30 January 2020

Published Online: 11 February 2020

In-Text Citation: (Jaffar et al., 2020)

To Cite this Article: Jaffar, S. R. A., Sujud, A., \& Muhammad, S. J. N. (2020). Vernacular Architecture in Old Malay Building through Malay Historiography. International Journal of Academic Research in Business and Social Sciences, 10(2), 266-276.

Copyright: (C) 2020 The Author(s)

Published by Human Resource Management Academic Research Society (www.hrmars.com)

This article is published under the Creative Commons Attribution (CC BY 4.0) license. Anyone may reproduce, distribute, translate and create derivative works of this article (for both commercial and non-commercial purposes), subject to full attribution to the original publication and authors. The full terms of this license may be seen

at: http://creativecommons.org/licences/by/4.0/legalcode

Vol. 10, No. 2, 2020, Pg. 266 - 276

http://hrmars.com/index.php/pages/detail/IJARBSS

JOURNAL HOMEPAGE

Full Terms \& Conditions of access and use can be found at http://hrmars.com/index.php/pages/detail/publication-ethics 


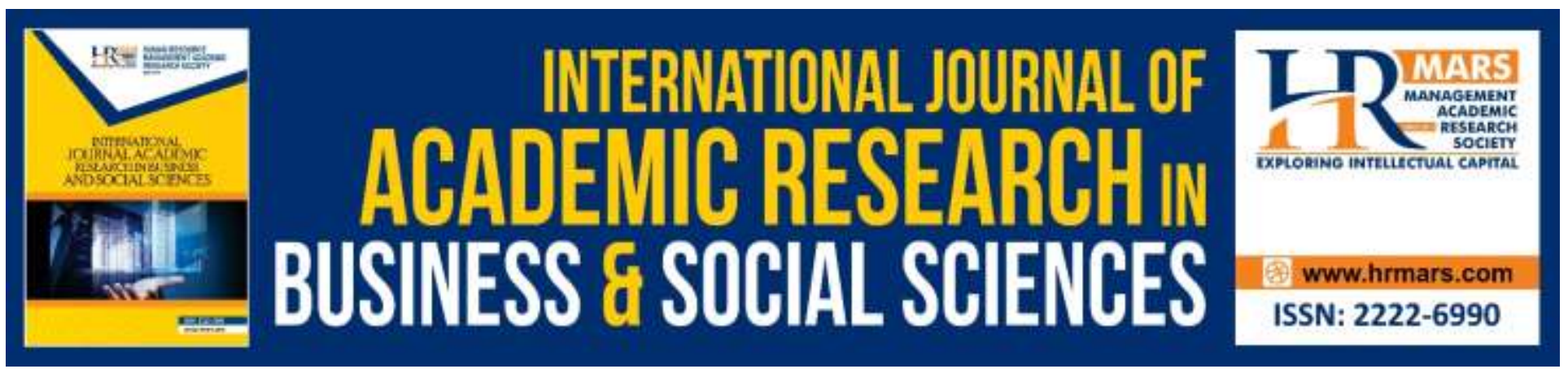

\title{
Vernacular Architecture in Old Malay Building through Malay Historiography
}

\author{
Siti Rabiatul Adawiah Jaffar \\ Centre for Fundamental Studies, Management \& Science University, Shah Alam Malaysia
}

Arba'ie Sujud, Salmah Jan Noor Muhammad

Faculty of Modern Language and Communication, Universiti Putra Malaysia, Serdang Malaysia

\begin{abstract}
Vernacular is said to be derived from the Latin term vernaculus which means domestic or local which means 'place'. However, in this context, the vernacular traditions clearly emphasize the conditions, local materials, environment and behavior as well as local customs that focus on traditional Malay society. This is reflected in the architecture that can be studied with the senses dependent on the thoughts and views of the community. Among them is the architecture of old Malay building. Research vernacular aspect of old Malay architecture displays a close link exists or affinity with nature and the community trust, which is the main source of living of the people. In fact, the nature and confidence in ensuring the community's ability to meet the objectives of old Malay income, as a protective domain, not only of the current situation, even include descriptions of culture. In this case, the old Malay architecture have been identified in the text of the Malay historiography, historical documentation as the material of the Malays. Hence, to highlight the description of the vernacular architecture of the old Malay, research will be conducted on the texts, intended to show the relationship of the Malay community with nature and belief, thus explaining its ability to meet the objectives of the production building old Malay, include their role as protectors of the current situation and highlights the value of Malay culture.
\end{abstract}

Keywords: Architecture of Old Malay Building, Nature, Islam, Vernacular, Malay Historiography Text.

\section{Introduction}

Vernacular in architecture is a term believed to be derived from the Latin, verna or vernaculus meaning domestic (familiar) and originally chosen by Rudofsky (1964), the founder of the use of the term, to classify local architecture. Later, the term vernacular is described in more detail when defined as building materials that are produced by local materials and construction technologies that adapt to the current climate in reflecting the culture and lifestyle of the people (Ravi, 2006). Vernacular architecture has also been described as a non-architectural design in accordance with the local climate, using local techniques and materials, influenced by the social, cultural and economic 
INTERNATIONAL JOURNAL OF ACADEMIC RESEARCH IN BUSINESS AND SOCIAL SCIENCES Vol. 10, No. 2, Feb, 2020, E-ISSN: 2222-6990 @ 2020 HRMARS

aspects of the local community (Mentayani \& Ikaputra 2012). It is also acknowledged by Octavia and Prawota (2019) that vernacular architecture is architecture that is developed without architecture, emphasized by emphasizing local aspects including the reliance on local sources, the receptiveness of the audience's desire to embrace diversity. He also emphasized that the vernacular architecture language has a historical application that not only focuses on aesthetics, but also its function. In this context, it is clear that vernacular architecture is a building based on local elements, including society, climate and environment, materials and techniques of local construction and influenced by its historical, aesthetic and functional aspects in describing its culture and way of life.

In this connection, several features of vernacular architecture research are emphasized, among others;

1. Construction involves the local community, without any specific knowledge of building architecture.

2. Built using local materials

3. Use some traditional techniques

4. Construction according to the environment (climate, culture and social)

5. Its production aims to meet the needs of its people today, including its physical and social needs

6. The outcome reflects the culture and lifestyle of his people.

Furthermore, vernacular architecture is clearly used in researching construction in every corner of the world, including Malaya. This is when Rudofsky (1964) introduced the concept of vernacular in architecture with the aim of classifying local buildings that focus on buildings (houses) in examining designs found at every corner of the globe (Mentayani \& Ikaputra, 2012). Furthermore, the Malay architecture was considered as a "vernacular architecture", when architecture clearly emphasizes the aspects of local, built by the Malays in the Malaya, based on the needs of the people, in reliance on natural resources and the environment, with the combination and reflects the way the life and culture of his people (Abidin et al., 2017).

In the meantime, Malay architecture that describes the characteristics of vernacular also shown by construction-old building, which is abundant in the Malay historiography. This includes record on the text such as Sulalatus Salatin and Misa Melayu. Studies based on these materials have proven their effectiveness compared to studies in other forms, as explained by Soebadijo (1974) that "information obtained from literature provides more information than information in other forms" (Soeratno, 2009). 


\section{Methodology}

This study uses the library method to obtain research data by reference to primary and secondary sources such as books, thesis, articles published in journals. There are four research methods planned in this paper, namely selecting, collecting, analyzing and summarizing data. At the data collection stage, the author researches the manuscript of choice in accordance with the research objective. Each reading on the contents of the manuscript is researched and recorded, especially the information that covers the topic of the study. Whereas in the data analysis phase, the focus is on the information obtained from the first stage while in the third stage, the information gathered will be analyzed to streamline the analysis process and the fourth level will be the overall conclusion on the topic of discussion.

\section{Analysis and Discussion}

\section{Construction Involves Local Communities, Without Special Knowledge of Building Architecture.}

Malay Building is generally produced by using a particular tradition, which is shown through construction techniques such as the use of oral tradition as a first step the production of a building. In this context, oral tradition is associated with presentation, including verbal and non-verbal traditions and practices that are not confined to the art of storytelling alone, but rather, to a wide range of fields including carpentry or architecture among its people. It is also stated, the art of old Malay building does not require a plan, but it is sufficient to simply describe the desired building orally (Daud, 2007).

Misa Melayu articulate Sultan Iskandar Zulkarnain's command on the design of a palace in Indera Sakti Island. Orally command, through oral presentation to the prince and his officials is one of the oral tradition that used by traditional Malay society. In fact, oral tradition in the context of society clearly shows its importance in the dissemination of knowledge and the development of knowledge thus shaping the process of socialization of the society. Malay architecture that relied on oral tradition showed the existence of vernacular architecture criteria when the building was built without certain systems, involving the construction plan, the architect of the special and specific knowledge regarding architecture and design. This is in line with Brunskill (2000) view of vernacular architecture, a building designed by amateurs without any training or knowledge in architecture.

\section{Its Production with the Purpose of meeting the Needs of its People, Includes Physical and Social Needs}

In addition, the production of a building is aimed of the current needs of the community which is to meet the needs of the local community (Yahya, 1995). These requirements pertain to protect themselves, their families and communities from various threats as defined by Ismail \& Selat (1992), a building constructed by traditional Malays serves as a refuge and residential protect humans from the various challenges of life, related to the environment including weather and wildlife. Therefore, to ensure that the purpose of construction of the building is met, the strength of the building is a key requirement in the construction of the building. Concentration should be given to the most important part that guarantees the strength of the building. 
Pillar is an important part of traditional Malay architecture of the building, which is the basis of stability and solidity of a building. The pillar plays an important role because of its function to bear the weight of the other part. It is related to the size of the part. To ensure the stability of the building is maintained, proper and appropriate pillar selection is a priority to ensure that the pillar can support the entire building including the roof and wall.

In the text of Sulalatus Salatin, it is expressed in the size of the roof and walls of the building, the seven-storey roof and the seventeen-room palace. Meanwhile, the pillar at the Sultan Mansur Syah palace is said to be of "sepemeluk" or an enfold. The use of large columns in the construction of the palace is closely related to the features found in the other part. The bigger or higher the space and the roof of the building, the larger the pillars will be. This is important to ensure the stability and robustness of the building. Pillars also considered to be the most important part of its function as a connector units were old Malay building. The connecting system on this pillar depends entirely on the component of the beam, which is the long timber connected from pillar to pillar through the holes in the pillar (Ismail \& Selat, 1992). This strength is in fact dependent on the strength of the "rasuk" (tie beam) component, which is obviously related to its elements of production. This includes the materials and the size of the tie beam.

Old Malay architecture described in Sulalatus Salatin showed suppression ratio and size of the "rasuk" on Mahligai Hawa Nafsu. In the "penanggahan" or kitchen area, the components of the "rasuk" were originally made of small size wood "Ibul". Sultan Mansur Syah, who was pleased with the overall construction of the palace, was not pleased with the "rasuk" components in the area, especially with the "rasuk pendek" (short beam), while the construction of the palace had seventeen spaces with a height of seven floors. As such, the "Bendahara" as head of construction replaced the "rasuk" with other tie beam that were larger, "sehasta" (a measure from the tip of the middle finger to the elbow) wide, "sejengkal tiga jari" (span between the tip of the thumb and fingers with three fingers) thick and made of wood "Kulim".

In the context of the study, the "rasuk" component was emphasized as the most important component to ensure the robustness of the castle. The strength of the "rasuk" depends on the type of material and the size of the component, as stated by Rashid (2010), the greater the load the "rasuk" carries, the greater the "rasuk" size required. Therefore, it is clear that choosing the right "rasuk" size can ensure the integrity and stability of a building.

\section{Built with Local Materials}

The stability of a building also depends on the choice of material in the production of "rasuk". This is to ensure the building is safe and secure. In the excerpt, "Bendahara" or Prime Minister replace components of wood Ibul beam to beam made of wood "Kulim" or Scorodocarpus, one of the species found in the vicinity of the Malaya. Scorodocarpus has certain characteristics that are suitable for use as building materials. They are hard and heavy, durable, have a smooth texture, are resistant to insect disturbance and have a wood fiber integrated (Dumanauw, 2001). Thus, it is clear that the characteristics contained in the Scorodocarpus be a major factor in choosing wood as the best wood in the construction of old Malay architecture. The selection of materials in construction, reflects the 
INTERNATIONAL JOURNAL OF ACADEMIC RESEARCH IN BUSINESS AND SOCIAL SCIENCES

Vol. 10, No. 2, Feb, 2020, E-ISSN: 2222-6990 @ 2020 HRMARS

existence of considerations in several respects, involves the availability of materials in meeting objectives, reaction to time and climate as well as being 'economic' (Heynen, 2019). Furthermore, the construction of old Malay palace focused on three aspects, namely environmental, economic, and social factors, which are then combined in the form of vernacular architecture (Abidin et al, 2017).

\section{Construction using Traditional Techniques in Accordance with Local Environment Conditions}

In the construction of a building, knowledge of the nature and environmental phenomena must be taken into account in ensuring that the building is able to ensure the social well-being of its people. This is mainly related to climate and local weather. Sulalatus Salatin depicts the roof of the Sultan Mansur Syah castle in accordance with the local climate through the design of the roof of "kapakapa" which is also known "bumbung lipat kajang" (as the folding roof) or "bumbung perahu" (the roof of the boat) (Iskandar, 2007). In fact, the roof also comes with "tebar layar berukir" (gable end engraving) and additional roof.

In this connection, the design of "lipat kajang" (a folding awning) on the roof of the palace is a design suitable for use in buildings in tropical climates, such as the Malay peninsula, including Melaka. This is because the roof design is able to withstand the challenges and pressures of local natural phenomena. Tropical climatic conditions generally experience hot and humid weather throughout the year, extreme temperatures, high average rainfall and strong winds during the monsoon season. Poor weather conditions can pose a serious threat to the safety and well-being of the people in the area, even affecting the construction of its buildings. Therefore, the problem can be solved by applying the roof design to the local climate conditions.

The suitability of the "bumbung lipat kajang" design is in line with the local climatic conditions because the roof has a steep roof design, which taps to the top and extends downward in the shape of an inverted $V$ shape. These designs can serve as projections that help facilitate the flow of rainwater that falls over the roof of the building directly to the ground. In addition, the widening of the roof can serve to protect the interior of the building, especially for non-walled space, from various weather threats such as rain and sun.

In addition, "bumbung lipat kajang" can also protect the occupants and buildings from the climatic pressures that create strong winds during monsoon season. This is related to openings on steep roofs that are said to be wider than other types of roofs. In fact, components on the roof such as the "tebar layar" (gable end) also help in the flow of the ventilation system for the roof of the building. Through Sulalatus Salatin, the "tebar layar" of the roof of the palace has various carvings as an opening component or also known as open vents. Through open air, it allows the movement of air through the building and thus helps to flow through the building. In the event of a strong wind phenomenon, the air can move freely through the opening component and thus secure the interior. In fact, to ensure the continuity of clean air flow to the interior of the building.

In the meantime, the ventilation system in the building of the old Malay is also associated with the opening in the wall part, which consists of windows, doors and open vents. This is because, the 
components help facilitate the air in and out of the building thus smoothing the ventilation system. Brief open component in the Mahligai Mercu Alam in Misa Melayu, the windows or "sengkuap" (the awnings) and "kisi-kisi" (the lattice) serves as a decorative window components, thereby helping to show the function of the structure of the building. These include facilitating the flow of air and light in and out of the building, limiting the outdoors and facilitating physical movement (Hanafi, Ahmad \& Jupri 1996). "Kisi-kisi" are considered open spaces placed on windows, made of various carvings and drawings. In fact, apart from the "kisi-kisi", the open vent component of the engraving type also plays a similar role, as a medium that facilitates the flow of air into and out of the building, thus assisting the ventilation system.

Through the Misa Melayu, function of carving on the palace of Sultan Iskandar Zulkarnain, helps the ventilation system at the palace. This is shown by the use of the phrase 'bunyinya ditiup angin itu seperti bunyi buluh perindu' (it sounded like a breeze). In this context, it is depicted that the carving of the "daun budi" (name of carved; leaves) produces a certain sound when the wind passes or passes through it. In other words, the "daun budi" are said to have open interiors, which allow the wind or air to pass through and produce a 'seperti buluh perindu' (bamboo-like sound).

\section{The Outcome Reflects the Culture and Lifestyle of his People}

Meanwhile, for the Malays, Islam is the religion, which is accepted as a form of behavior that is inherited from generation to generation in the society, practiced and upheld in all public life. The practice of the community associated with Islam is one of the ritual of societies. For example, the practice of worship such as prayer, fasting and tithe (Idris et al., 2012). In other words, the practice is much emphasized in the daily lives of the Malay community. In a way, Islam is also absorbed in the production of old Malay architecture, especially in the design (Jaffar et al., 2018).

Through Misa Melayu, shows the practice of prayer, which is the ritual of the Muslim Malay community at the time. The practice also described the function of the hall in the palace of Sultan Iskandar Zulkarnain as a place of prayer, held with sultans, priests and officials. In this context, the architecture is through the space station to explain the existence of patterns of Islamic life in architecture building traditional Malay as highlighted by Rasdi \& Tajuddin (2004), which states there is a combination of the effects of lifestyle of the Malay community in the construction its buildings, including the impact of the Islamic life pattern as an important element in the building planning plan.

The pattern of Islamic life underpinning the construction of buildings through the use of space as a place for rituals is also reflected in the existence of customary ceremony involving religious rituals. For example, in the Malay wedding customs, also involving religious rituals through "akad nikah" (marriage ceremony). "Akad nikah' is an important ceremony and is regarded as the starting point for endorsing or legalizing the relationship between a man and a woman as husband and wife (Jabatan Kemajuan Islam Malaysia, 2013). In the text of historiography, described symbols exist, related to the architecture of the old Malay buildings that show a marriage bond as the basis for the formation of a family. Misa Melayu explains Malay marriage ceremony held at the "balai penghadapan" (a hall where homage is paid to king) of Berahman Indera Palace. "Balai penghadapan" in this context is located at the front of the palace, which is the first room of the front before entering 
INTERNATIONAL JOURNAL OF ACADEMIC RESEARCH IN BUSINESS AND SOCIAL SCIENCES Vol. 10, No. 2, Feb, 2020, E-ISSN: 2222-6990 @ 2020 HRMARS

the space inside the palace. The "akad nikah" held in that room symbolized the beginning before entering the life of marriage made through the "lafaz nikah" (marriage vows) according to the position of the "balai penghadapan", the first room before entering the palace. In this study, it is clear that "balai penghadapan" in this context is a symbol of the "lafaz nikah" or marriage vows, while the palace is a symbol of marriage life.

Furthermore, this feature of vernacular architecture also focuses on decorative design. The appreciation of the natural objects have yielded ideas in the production of Malay decorative design. This is shown through the use of old Malay building. Misa Melayu featuring sulur bayung (name of decorative design) on the roof window of Balai Panca Persada, derived from plant buds impersonation Bayung/ Lembayung or Basella (Mohd, 1989). These motifs are among the most frequently chosen ones of the artist especially the sculptor of a building or residence. This is because, the spinning motif has its own special advantages through its design research which shows that the motifs of plants intertwine and form a circle (Bakar \& Utaberta, 2013).

Privileges sulur bayung on Malay building, has to do with the position of the motives. This is when the sulur bayung is widely used at the apex or roof, either the roof of the building or the roof of the window (Harun \& Othman, 2011). Misa Melayu shows the use of sulur bayung on the roof of the palace at Indera Sakti Island. The tendency of the Malay community in displaying the motif on the roof, is closely related to public opinion in the interpretation of the decorative design. Sulur bayung for the Malay community symbolizes man's relationship to the Creator (Allah s.w.t), through prayer. This is reflected in the shape of a circle on the motif that resembles the human hand performing the prayer (Harun \& Othman, 2011). In fact, it also describes the motives of politeness within the community, that is the humble and not arrogant as advocated in Islam (Mohamad \& Kiram, 2010).

In the same time, the use of decorative design on a traditional Malay building also makes the animals as a source of impersonation known as fauna motifs. Use Motive fauna fact closely related to the element of belief in Malays (Malaysia, 2009). It is driven by a specific factor that has to do with the physical characteristics of the animal that was seen as a manifestation of education and reminders to yourself, and the Malay descent (Haron et al, 2014). Through Misa Melayu, described the use of a dragon motif on Balai Panca Persada through the physical characteristics of the carved dragon motif that has a "sisik emas" (golden scales), "cula dari manikam" (horns from rubies) and "mata dari mutiara merah" (eye from red pearls). Use of dragon motif that emphasizes physical characteristics showing manifestations of education through the description of thought as a symbol of strength and courage as specified by Haron, Yusof, Taha \& Mutalib (2014), dragon motif resulting in Malay society is based on the character physically strong and great, as a symbol of bravery and power over evil creatures. He also emphasized the production of such motifs that originated in the social realm, as a result of depictions of folk tales and folk tales as told by Tok Dalang or a "Penglipur Lara".

However, after the advent of Islam, the appraisal of dragon-motif-carving art changed according to the principles and beliefs outlined. Dragon motif on the buildings is regarded as the symbol of Malay humility (Mohamed, 1989). It is basically linked to the trust that the community considers dragon as a creature of Allah s.w.t and admire his creation. This creates a sense of sincerity and humility in the 
human body as a servant, thus fostering a sense of faith and piety. Similarly, the carving of dragons in water transport, which clearly leads to the belief in the spirit and motivation of helping people to make a living (Ahmad, 1999).

The production of dragon motif in this context come from the taste of the community about the beauty of the physical characteristics of a dragon obtained from the study of the social world, that is through the telling of stories, legends and folklore. Based on this physical description, it is the values of strength, courage and humility that influence his thinking and behavior. Thus, the motives of the dragon, which served as a medium of deregulation, were designed to educate people towards the formation of their society's moral values.

\section{Conclusion}

Based on the definitions stated by some scholars, several important features have been identified to study vernacular architecture. Features of the new guidance in explaining the vernacular architecture in the old Malay building construction including the text of the Malay historiography. Through characteristic, shows that Malay vernacular architecture includes three important aspects, namely, material, technical and social. all three of these aspects are affected local elements, which are then combined to reflect about the culture and lifestyle of the community, indirectly shows the relationship with the community environment. About faith also be a measure of the income of old Malay architecture. This is when the aspect of religious education forms the basis of its design as well as the image of education as the background of income. Therefore, it is hoped that the study of vernacular architecture through text will be presented to the public so that this knowledge will continue to be known throughout the ages.

Previous studies on vernacular architecture focused more on field studies, which focused on existing structures. However, this paper focuses on the study by clear text, to see how the text explains the existence of Malay historiography features built in old Malay vernacular. Based on the identified features of the vernacular architecture, it provides a new guideline for the study of vernacular architecture, thus contributing to subsequent studies in related studies. In addition, research by the text, that text Historiography of Malay as a text document concerning all aspects of the community, including a description of its architecture and proven architecture of the old Malay text through the application of vernacular architecture in construction.

\section{Corresponding Author}

Siti Rabiatul Adawiah Jaffar, Centre for Fundamental Studies, Management \& Science University, Malaysia. sitirabiatul_adawiah@msu.edu.my, Centre for Fundamental Studies, Management \& Science University, University Drive, Off Persiaran Olahraga, Seksyen 13, 40100 Shah Alam, Selangor Darul Ehsan.

\section{References}

Abidin, N. Z., Shahminan, R. N. R., \& Ibrahim, F. K. (2017). Sustainable Mid-Rise Vernacular Palace Architecture of Istana Lama Seri Menanti, Negeri Sembilan. Pertanika Journal of Science and Technology, 25, 29-36.Ahmad, A. S., \& Salatin, S. (1979). Kuala Lumpur. Dewan Bahasa dan Pustaka. 
INTERNATIONAL JOURNAL OF ACADEMIC RESEARCH IN BUSINESS AND SOCIAL SCIENCES

Vol. 10, No. 2, Feb, 2020, E-ISSN: 2222-6990 ¿ 2020 HRMARS

Ahmad, I. (1999). Pengangkutan diair dalam budaya melayu. Dewan Bahasa dan Pustaka.

Bakar, A. A., \& Utaberta, N. (2013). Motif-Motif Ukiran Pada Rumah Tiang Dua Belas Di Kelantan Dan Terengganu. Journal of Design+ Built, 6 .

Basri, M. F. M. (1992). Misa Melayu. Dewan Bahasa dan Pustaka, Kementerian Pendidikan Malaysia.

bin Mohamed, A. (1980). Falsafah dan Pemikiran Orang-orang Melayu. Hubungannya dengan Islam dan Kesenian, Kementerian Kebudayaan, Bella dan Sukan.

bin Mohd, O. (1989). Warisan kesenian dalam tamadun Islam. Kementerian Pendidikan Malaysia, Dewan Bahasa dan Pustaka.

binti Jaffar, S. R. A., Arba'ie bin Sujud, S. J., Muhammad, N., binti Kamarudin, K., \& binti Abdul, N. S. (2018). Malay Building Design Reflecting the Importance of Women in the Malay Manuscript. INTERNATIONAL JOURNAL OF ACADEMIC RESEARCH IN BUSINESS AND SOCIAL SCIENCES, 8(8), 639-646.

Brunskill, R. W. (2000). Vernacular architecture: An illustrated handbook. Faber.

Daud, H. (2007). Tradisi Lisan: Ilmu Perbomohan” dalam Rogayah A. Hamid \& Wardawati Md. Sheriff. Tradisi Lisan: Manifestasi Cendikiawan Melayu.

Dumanauw, J. F. (1990). Mengenal kayu. Kanisius.

Hanafi, Z., Ahmad, A. G., \& Jupri, S. N. (1996). Pembinaan bangunan tradisional Melayu. AmberSolara Publication.

Haron, H., Yusof, N. A., Taha, M., \& Mutalib, N. A. (2014). Motifs of Nature in Malay Traditional Craft. Middle-East Journal of Scientific Research, 21(1), 169-180.

Harun, R., \& Othman, F. Traditional Ecological Knowledge (TEK) in Selected Heritage Mosques of Malacca, Malaysia.

Hassan, A. J. M. (1993). Perkahwinan dalam Islam Berdasarkan Kepada Dalil, Hukum, Hikmat dan Panduan Kebahagiaan (Marriage in Islam Based on The Evidence, Law, the Guide of Wisdom and Happiness). Kuala Lumpur: AS Noorden.

Heynen, H. (2019). vernacular architecture and the uses of the past.

Idris, F., Suradi, N. R. M., Muhamad, S., Mastor, K. A., \& Kasan, H. (2013). A Path Analysis Approach on the Effects of Faith Based Behavior on Religious Delinquent Behavior Among Youth. Research Journal of Applied Sciences, 8(1), 89-95.

Iskandar, T., \& Zainal, B. (2007). Kamus Dewan: Edisi Keempat. Kuala Lumpur: Dewan Bahasa dan Pustaka, cetakan kedua.

Ismail, M. H., \& Selat, N. (1992). Rumah Tradisional Melayu Melaka. Persatuan Muzium Malaysia, Muzium Negara.

Ismail, S. Z. (1986). Rekabentuk kraftangan Melayu tradisi. Dewan Bahasa dan Pustaka, Kementerian Pelajaran, Malaysia.

Jabatan Kemajuan Islam Malaysia. (2013). Garis Panduan Upacara Akad Nikah Di Masjid Dan PerkaraPerkara Yang Berkaitan Dengannya. Perpustakaan Negara Malaysia.

Mahali, S. N. H. (2007). Unsur bahasa dalam budaya. Penerbit UMS.

Malaysia, K. (2009). Ukiran kayu warisan Melayu. Kuala Lumpur: Perbadanan Kemajuan Kraftangan Malaysia.

Mentayani, I., \& Ikaputra, A. (2012). Menggali Makna Arsitektur Vernakular: Ranah, Unsur, dan Aspek-Aspek Vernakularitas. LANTING Journal of Architecture, 1(2), 68-82. 
INTERNATIONAL JOURNAL OF ACADEMIC RESEARCH IN BUSINESS AND SOCIAL SCIENCES

Vol. 10, No. 2, Feb, 2020, E-ISSN: 2222-6990 @ 2020 HRMARS

Mohamad, H., \& Kiram, N. H. M. (2010). Pendekatan sosioterminologi dalam pengistilahan seni kraf Melayu.

Nasir, A. H. (1985). Pengenalan Rumah Melayu Tradisional Semenanjung Malaysia [trans. Introduction to the Traditional Malay Houses in Peninsula Malaysia]. Kuala Lumpur, Darulfikir.

Octavia, L., \& Prawoto, E. (2019). Membaca dan Memaknai Ruh Keberlanjutan dalam Arsitektur Vernakular.

Oliver, P. (Ed.). (1997). Encyclopedia of vernacular architecture of the world (Vol. 3). Cambridge: Cambridge University Press.

Ralim, H. A. (1988). Asas pembinaan rumah. Dewan Bahasa dan Pustaka.

Rasdi, M., \& Tajuddin, M. (2004). Warisan seni bina dunia melayu rumah-rumah tradisional.

Rashid, A. A. (2010). Rekabentuk Rasuk Kayu Menggunakan MS544 Dan BS 5268: Kajian Kesan Saiz (Doctoral dissertation, Universiti Teknologi Malaysia).

Rashid, N. A. (2005). Nilai kesantunan dalam konteks sosiobudaya masyarakat Melayu. Jurnal Pengajian Melayu, 15(1), 232-253.

Ravi, S. S. (2006). Defining „Vernacular": Changing Vernacular Houses around Varanasi, UP (India) Durckheim 1925 Les formes elementaires de la vie religieuse. Felix Alcan Paris.

Rudofsky, B. (1987). Architecture without architects: a short introduction to non-pedigreed architecture. UNM Press.

Soeratno, S. C. (2009)."Peranan Naskhah Melayu bagi Kehidupan di era Global."Melestarikan Manuskrip Melayu Warisan Agung Bangsa: Kumpulan Kertas Kerja Seminar Antarabangsa manuskrip Melayu.

Shuaib, A. A. (2011). Seni ukiran kayu tradisional Kelantan-manifestasi nilai pengukir

Yahya, M. A. (1995). Simbolisme dalam seni bina rumah Melayu Kelantan. Dewan Bahasa dan Pustaka, Kementerian Pendidikan, Malaysia.

Yuan, L. J. (1987). The malay house. Institut Masyarakat Malaysia. 